\title{
The positive effect of role models in evolution instruction
}

\author{
Emily A. Holt ${ }^{*}$, T. Heath Ogden² and Susan L. Durham ${ }^{3}$
}

\begin{abstract}
Background: Previous research has identified numerous factors to explain why students have difficulty learning about evolution. Some of these factors include a student's background (including their religion and major of study), the type of evolution instruction, and the inclusion of the nature of science (NOS) instruction. Sparse but more recent work has investigated the impact of a religious-scientist role model to help dampen perceptions of conflict between evolutionary science and worldview. We had two research goals: (1) to identify which of these factors influence students' learning of evolution in post-secondary education; and (2) to describe the relationships among incoming biology students' creationist reasoning, knowledge of evolution, and perceived conflict between evolution and their worldview.

Results: The single factor linked with the reduction in both creationist reasoning and in students' perceived conflict between evolution and their worldview through a semester was the presence of a role model. Likewise, knowledge and perceived relevance of evolution increased in sections with a role model instructor and with evidence-based evolution instruction. Otherwise, tested factors (the type of evolution instruction, inclusion of NOS, biology-major/ nonmajor, GPA, or religiosity) were not shown to be associated with these three constructs. We found that in the first week of the semester students with higher knowledge of evolution had lower creationist reasoning and lower perceived conflict.

Conclusions: The single factor that collectively reduced erroneous beliefs, increased scientific knowledge, and minimized perceived conflict was the presence of a religious-scientist role model. Previous work has suggested a role model could positively impact students'learning of evolution, yet this is the first quasi-experimental evidence supporting the importance of the course instructor as the role model in students'learning of evolution. These findings are especially relevant to institutions with a greater proportion of religious students who could benefit from modeling to help foster their learning of evolution.
\end{abstract}

Keywords: Evolution, Mormon, Role model, Nature of science, Religion

\section{Background}

Evolution is the cornerstone to modern biology. Its importance in our understanding and advancement of medicine, agriculture, environmental and species management, among other areas of science, has repeatedly been documented (Dobzhansky 1973; Fail 2008; Gould 2002; Mayr 1982; Sager 2008; Wiles 2010). However, previous reports suggest that $46 \%$ of Americans reject

\footnotetext{
*Correspondence: emily.holt@unco.edu

'School for Biological Sciences, University of Northern Colorado, Greeley, USA

Full list of author information is available at the end of the article
}

human evolution (Miller et al. 2006; Newport 2012). The US still lags far behind many other countries in terms of the acceptance of evolution (Miller et al. 2006; Pew 2014a).

This rejection of evolutionary science in the US mainly stems from misunderstanding of the nature of science (Dunk et al. 2017; Glaze et al. 2015) and religiosity (Barnes et al. 2017a; Glaze et al. 2015; Rissler et al. 2014). Distrust and rejection of evolutionary theory has been correlated with a belief in a Christian God-creator (Allmon 2011; Gallup 2007; Heddy and Nadelson 2013; Moore et al. 2011). Such religious beliefs are sometimes associated with fatalism, or a perception of an external 
locus of control, where the origins and diversity of life are attributed to divine or extraterrestrial beings (Krause 2007; Schieman et al. 2006; Wade 1996). Outside the interplay of religion and evolutionary science, overall distrust of science as a whole by the American public confounds the problem (Hokayem and BouJaoude 2008; Kahan 2013; McCright et al. 2013; Nadelson and Hardy 2015).

More recent polls continue to document low acceptance of human evolution in the US [57\% (Gallup 2017) and $62 \%$ (Pew 2015) acceptance], despite declining religiosity among the American people (Pew 2013). As science educators, we hope instruction in the public education systems increases students' understanding of evolution. However, Bowman (2008) suggests that secondary education in the US presents evolution as a concept lacking credibility as much as $40 \%$ of the time. As a result, biology education research at the university-level has focused on increasing student acceptance and understanding of evolution through instruction (Ingram and Nelson 2006; Wiles and Alters 2011).

Unfortunately understanding and acceptance of evolution, as individual constructs, are intermingled, and research describing their relationship draws mixed conclusions. Some studies report correlations between understanding, or knowledge, of evolution and acceptance of evolution (e.g., Abraham et al. 2012; Carter et al. 2015; Ingram and Nelson 2006; Nettle 2010; Manwaring et al. 2015; Rutledge and Warden 2000). Meanwhile, others contradict the idea that understanding and acceptance are related (e.g., Bishop and Anderson 1990; Lawson and Worsnop 1992; Lloyd-Strovas and Bernal 2012; Nadelson and Sinatra 2010). Additionally some published surveys contain items that confound acceptance and understanding (e.g., a student must use both their understanding of evolutionary theory and acceptance thereof to answer a question). We recognize that it can be difficult to assess both acceptance and understanding separately with certain tools that cannot disentangle the two, and even more challenging to investigate any correlation or causation between the two. Thus, this paper does not address this problem specifically. Rather, we investigated students' change in understanding and perceptions of evolutionary theory, which includes both acceptance and understanding, and related influential factors to improve evolution education post-secondary classrooms over a semester of instruction.

Among the many factors that potentially influence students' acceptance or understanding of evolution highlighted in the literature, four are consistently identified as key drivers. The first factor, linked with both understanding and acceptance, is students' difficulty finding congruence between evolution and their personal beliefs (Lawson and Worsnop 1992; Lloyd-Strovas and Bernal 2012; Manwaring et al. 2015) or prior life experiences (Carter et al. 2015; Moore et al. 2011). A student's worldview is sculpted by religion, culture, politics, and education. Generally, more conservative and/or religious individuals have lower acceptance of evolution (Mazur 2005; Nadelson and Hardy 2015). For religious students, new scientific knowledge may be only superficially integrated for fear it may displace or discredit their previous worldviews (Allmon 2011; Schilders et al. 2009). Significant carry-over effects from erroneous content in high school biology courses has been shown to negatively impact students' knowledge and perceptions of evolution (Carter et al. 2015; Moore et al. 2009; Moore and Cotner 2009; O'Brien et al. 2009).

A second factor, again linked with both understanding and acceptance, is lack of effective evolution instruction (Lloyd-Strovas and Bernal 2012). A clear link between university instruction and students' increased knowledge and acceptance of evolution is debated (Abraham et al. 2012; Ingram and Nelson 2006; Lawson and Worsnop 1992); however, certain approaches may lead to better student outcomes. For instance, evolution instruction using human examples rather than non-primate animals or other organisms could reduce misunderstandings and increase acceptance (Nettle 2010; Pobiner 2012, 2016). Helping students actively draw connections between evolutionary science and their everyday lives can be a transformative experience that promotes conceptual change (Heddy and Sinatra 2013). Evidence-based instruction, where students draw conclusions directly from real data, can facilitate growth in evolutionary knowledge (Romine and Todd 2017).

A third factor is students' understanding of the nature of science (NOS) that previous literature has associated with evolution acceptance (Cavallo and McCall 2008; Lloyd-Strovas and Bernal 2012; Lombrozo et al. 2008; Rutledge and Mitchell 2002) and potentially even with evolution understanding (Nehm and Schonfeld 2007). Even when controlling for confounding factors, including background knowledge and positive attitudes towards science, evolution acceptance is positively correlated with an understanding of NOS (Lombrozo et al. 2008). Acknowledging students' preconceptions about the diversity and origins of life, in parallel with instruction based on scientific explanations, may dispel their internal conflict and increase their evolution acceptance (Matthews 2001).

Fourth, a student's major of study is a factor previously associated with both understanding and acceptance of evolution and also serves as a proxy for student interest and potentially their past exposure to evolution. Nadelson and Southerland (2010) found that both evolution 
understanding and acceptance was positively associated with the amount of university-level biology coursework a student had taken, which tends to be greater for those majoring in biology. Students enrolled in an introductory biology course for majors outside of biology tend to have lower acceptance and understanding of evolution than students enrolled in a biology majors' introductory course (Partin et al. 2013). Within the same biology course, science and engineering students had greater evolutionary knowledge and acceptance levels compared to students of other majors (Hermann 2016). Paz-y-Miño and Espinosa (2009) describe that significantly more nonmajors than majors felt uncomfortable learning about evolution because it conflicted with their faith, suggesting that a student's major may be related to their acceptance of evolution.

A final, fifth factor that is not commonly linked to students' acceptance or understanding of evolution, but that we hypothesized may be important in our study population, is the presence of a role model-one who both accepts evolution and is religious. Religious-scientist role models have been shown in previous research to positively influence students' views on the relationship between religion and evolution acceptance (Winslow et al. 2011; Barnes and Brownell 2016; Barnes et al. $2017 \mathrm{~b}, \mathrm{c})$. Over $80 \%$ of our study population are members of the Church of Jesus Christ of Latter-Day-Saints (LDS), also known as the Mormons. Members of this religious population often hold deep-seated beliefs against evolution (Heddy and Nadelson 2013; Manwaring et al. 2015). In a Pew (2009) study, the LDS denomination had the second lowest agreement that evolution is the best explanation for the origin of man (22\%), well below the reported national average $(48 \%)$. In a more recent poll $42 \%$ of Mormons surveyed agreed with the statement that "Humans and other living things have evolved over time" (Pew 2014b). While acceptance rates have increased within this group, their rates are still below the national average of $58 \%$, and Mormon students are often unaware of the LDS Church's neutral stance on evolution (Manwaring et al. 2015). Notably, Mormonism places a large value on authority and role models (Crapo 1987), and faculty identity has been demonstrated to impact student actions in other fields (Bettinger and Long 2005).

Social cognitive career theory posits that modeling plays a critical role in self-efficacy and directing occupational interests (Lent et al. 2002; Gibson 2004). Moreover, a body of literature suggests that role models can buffer the impact of stereotype threat (Marx and Roman 2002; Stout et al. 2011). In the current study, stereotype threat may manifest as students' concern about conforming to low acceptance of evolution among Mormons. Therefore a positive role model, i.e., a professor who is both an outwardly devout Mormon and a scientist accepting of evolution, may allow students to be more open to learning about evolution, which may change both their acceptance and understanding of evolution. Winslow et al. (2011) is the only other study to investigate a link between faculty role models and learning of evolution; their work was based on interviews rather than outcomes and focused solely on evolution acceptance.

We were interested in examining students' change in understanding and acceptance of evolutionary theory over a semester of instruction. Specifically, our first research goal was to identify which factor(s) have the greatest influence on students' understanding and acceptance of evolution in a university setting. We focused our research on three testable factors that we as the researchers could manipulate: (1) evolution-instruction approach (conceptual with plant and non-primate animal examples versus evidence-based including human examples); (2) presence or absence of NOS instruction; and (3) presence or absence of a role model. We also considered student characteristics outside of our control: (1) class (i.e., biology majors versus non-majors); (2) religiosity; and (3) grade point average. We measured students' understanding and acceptance of evolution using three constructs: creationist reasoning, knowledge and relevance of evolution, and perceived conflict between evolution and their worldview. Our second research goal was to describe the bivariate relationships among these three constructs in university students measured during the first week of an introductory biology course to describe students' preconceptions and how they interrelate.

\section{Methods}

\section{Participants and survey instruments}

We surveyed students in eight sections of introductory biology at a public post-secondary institution in the western US. Our full sample included 1339 students, surveyed during Fall 2012, Spring 2013, and Fall 2013. Surveys were administered online during the first and last weeks of each semester, and responses were collected using Survey Monkey (https://www.surveymonkey.com). Many students did not complete both pre and post-surveys or unique identifier information was inadequate to link their responses longitudinally (478 students), or key demographic variables of interest were missing (42 students); therefore, only 819 students who had complete pre- and post-data for the three constructs plus grade-point average (GPA) and religiosity scores were retained for analyses. Of those, $30 \%$ were freshman, $41 \%$ were sophomores, $21 \%$ were juniors, $6 \%$ were seniors, and $3 \%$ were postbaccalaureate. The mean GPA on a $0.0-4.0$ scale was 3.38. Most of the students considered themselves religious; $44 \%$ (363 of 819 students) self-identified as "very 
religious" and 75\% (613 students) classified their degree of religiosity as "quite a bit" or "very religious", while the remaining quarter classified themselves as "moderately", "a little" or "not at all" religious. Eighty-four percent identified themselves as Mormon. Two instructors taught the surveyed sections; one instructor taught five sections and the other taught three sections.

An abbreviated form of the Evolutionary Attitudes and Literacy Survey (EALS; Hawley et al. 2011; Short and Hawley 2012) was used to quantify student religiosity (RA), creationist reasoning (CR), and understanding of the knowledge/relevance of evolution (KR). The latter two constructs represent a combination of student understanding and acceptance of evolution (as classified by the current authors; Appendix 1: Table 3). Our version of this survey contained 55 of the original 80 items in 11 lower-order factors representing the three higherorder constructs identified above (Appendix 1: Table 3). We also used seven items to quantify a fourth construct: students' perceived conflict between science and their worldview (CO; Bailey et al. 2011), which was a measure of conflict (Appendix 1: Table 3). All 62 items within these four constructs were rated on a 5-level Likert scale. All four constructs were highly or acceptably reliable (Nunnally and Bernstein 1994) using our study population (Cronbach alpha: $\mathrm{RA}=0.95, \mathrm{CR}=0.89, \mathrm{KR}=0.83$, $\mathrm{CO}=0.71)$. Eleven items were reversed scored, and then items within each construct were averaged for analysis. Surveys also included demographic questions and longitudinal identifiers. GPA was the only demographic variable we included as an explanatory variable of interest as a proxy of students' overall performance in college.

\section{Treatments}

We addressed four possible drivers of positive change in student knowledge and acceptance of evolution (Table 1). First, we hypothesized that the type of evolution-instruction content would be a main driver in change. We implemented two types of instruction, conceptual and evidence-based. The conceptual instruction presented evolution as a set of concepts (e.g., fitness, natural selection, gene flow, genetic drift) which used all plant or non-primate animal examples, while the evidence-based instruction presented evidence for evolution using published data, including human examples. The evidencebased instruction required that students construct foundational principles of evolutionary theory using evidence from data, and this evidence often conflicted with creationist religious constructs.

Second, literature suggests that inclusion of nature of science (NOS) instruction is important for students' evolution acceptance and understanding. Four sections lacked any explicit NOS instruction, while the other four
Table 1 Number of students within each of the treatment combinations

\begin{tabular}{|c|c|c|c|c|}
\hline & \multicolumn{2}{|c|}{ Role model absent } & \multicolumn{2}{|c|}{ Role model present } \\
\hline & Nonmajors & Majors & Nonmajors & Majors \\
\hline \multicolumn{5}{|l|}{ NOS absent } \\
\hline Evidence-based content & $\mathrm{n} / \mathrm{a}$ & 27 & $\mathrm{n} / \mathrm{a}$ & $\mathrm{n} / \mathrm{a}$ \\
\hline Conceptual content & 27 & 77 & $\mathrm{n} / \mathrm{a}$ & $\mathrm{n} / \mathrm{a}$ \\
\hline \multicolumn{5}{|l|}{ NOS present } \\
\hline Evidence-based content & 202 & 22 & 464 & $\mathrm{n} / \mathrm{a}$ \\
\hline Conceptual content & $\mathrm{n} / \mathrm{a}$ & $\mathrm{n} / \mathrm{a}$ & $\mathrm{n} / \mathrm{a}$ & $\mathrm{n} / \mathrm{a}$ \\
\hline
\end{tabular}

Not all treatment combinations were observed (labeled as "n/a")

dedicated several class sessions to the NOS. This NOS instruction framed science as one of many ways of knowing and clearly articulated the types of claims science can and cannot address. Students were shown images and direct quotations of well-known religious entities (i.e., leaders from the Church of Jesus Christ of Latter-DaySaints, Pope John Paul II, the Dalai Lama) which clearly acknowledge science and religions as each having their place in answering different questions of the human experience.

Third, the literature suggests that biology majors have greater knowledge and less conflict with evolution compared to students of other majors. Four sections were from a non-majors course, while the remaining four sections were from a biology-majors course; both represent the introductory biology course for each group of students.

Fourth, an instructor who both accepts evolution and is openly devoted to his/her Mormon faith may influence students' understanding and acceptance of evolution as a role model. One of our participating instructors explicitly served as this religious-scientist in two sections and as a non-role model during one section by avoiding any reference or clues that he/she was a highly devout Mormon. The other instructor who never mentioned their personal religious beliefs taught the remaining five sections. Teaching assistants who interacted with students informally reported that many students perceived their non-role model instructor as a non-believer. During a class discussion, one student even pointedly asked their non-role model instructor if they believed in God, implying doubt.

\section{Other explanatory variables}

In addition to the four explanatory variables that characterized classrooms (i.e., type of evolution instruction, inclusion of NOS, major/non-major class, presence of a role model), we included our measure of religiosity 
(Religious Activity; a higher-order construct derived from the EALS; Hawley et al. 2011; Short and Hawley 2012) and GPA as possible predictors of our three constructs. Religiosity often drives an individual's worldview that can then influence their perceptions of evolution (Mazur 2005; Nadelson and Hardy 2015). We anticipated that GPA may serve as a surrogate for a student's overall university performance and may relate to their ability to learn new information.

\section{Unit of analysis}

The statistical analyses assume that each student is independent of all other students. In actuality, students are clustered by section, and all students in the same section receive the same "treatment" (i.e., the same instructor delivering the same content to all students at the same time). Ideally, the appropriate experimental unit would be a section; however, time and resources necessitated deviations from this analytical standard. Using students as independent replicates is classical pseudoreplication ( Hurlbert 1984) and results in liberal hypothesis tests; consequently, we implemented a conservative approach to assessment of "significance".

\section{Data analyses}

We conducted separate analyses for creationist reasoning (CR), knowledge and relevance of evolution (KR), and conflict between evolution and worldview $(\mathrm{CO})$ scores using statistical models with the same structure. Fixed effects factors in the statistical model included the four explanatory variables that characterized class sections (i.e., type of evolution instruction, inclusion of NOS, major/non-major class, presence of a role model), GPA and baseline religiosity score, plus the baseline construct score to assess change over the semester at the individual student level. Due to the lack of data for many combinations of class section factors (Table 1), no interactions among the four class section factors were included, and we considered probable bias as we interpreted results. We included the three-way interactions of GPA, baseline construct score and each of the four class section factors, and the three-way interactions of religiosity score, baseline construct score and each class section factor. GPA, religiosity score, and baselines scores for CR, KR, and $\mathrm{CO}$ were each centered on their respective overall means. Reported means and standard errors were estimated at the overall means of baseline construct scores, GPA, and religiosity. As needed to interpret and depict interactions, means were estimated at the 10th, 50th, and 90th percentiles of baseline construct scores. Data computations were made using the GLIMMIX procedure in SAS/ STAT 14.3 in the SAS System for Windows 9.4 TS1M5. Model assumptions of normality, homogeneity of variance, and linearity were evaluated using graphical assessment of residuals.

\section{Results}

Descriptive statistics for baseline scores for each construct for each of the four class section factors are presented in Table 2.

\section{Factors driving creationist reasoning, evolutionary knowledge, and conflict}

Our first research goal was to identify the main drivers of change in student knowledge and acceptance of evolution, using three constructs. In general, creationist

Table 2 Descriptive statistics for baseline construct scores for each class-section factor

\begin{tabular}{|c|c|c|c|c|c|c|c|c|c|}
\hline \multirow[t]{2}{*}{ Construct } & \multirow[t]{2}{*}{ Statistic } & \multicolumn{2}{|c|}{ Instruction content } & \multicolumn{2}{|c|}{$\begin{array}{l}\text { Inclusion } \\
\text { of NOS }\end{array}$} & \multicolumn{2}{|l|}{ Class } & \multicolumn{2}{|c|}{$\begin{array}{l}\text { Role-model } \\
\text { instructor }\end{array}$} \\
\hline & & Conceptual & Evidence based & No & Yes & Nonmajor & Major & Absent & Present \\
\hline \multirow[t]{4}{*}{ Creationist reasoning (CR) } & Minimum & 1.08 & 1.08 & 1.08 & 1.08 & 1.08 & 1.26 & 1.08 & 1.08 \\
\hline & Mean & 2.55 & 2.68 & 2.50 & 2.70 & 2.70 & 2.50 & 2.65 & 2.68 \\
\hline & Median & 2.65 & 2.74 & 2.60 & 2.75 & 2.75 & 2.52 & 2.70 & 2.75 \\
\hline & Maximum & 4.19 & 4.00 & 4.19 & 4.00 & 4.00 & 4.19 & 4.19 & 3.92 \\
\hline \multirow[t]{4}{*}{ Knowledge and perceived relevance (KR) } & Minimum & 2.03 & 1.92 & 2.03 & 1.92 & 1.92 & 2.75 & 1.92 & 2.30 \\
\hline & Mean & 3.59 & 3.38 & 3.61 & 3.37 & 3.37 & 3.60 & 3.37 & 3.43 \\
\hline & Median & 3.55 & 3.35 & 3.58 & 3.35 & 3.35 & 3.56 & 3.34 & 3.41 \\
\hline & Maximum & 4.96 & 4.82 & 4.96 & 4.82 & 4.96 & 4.66 & 4.96 & 4.82 \\
\hline \multirow[t]{4}{*}{ Conflict between evolution and worldview (CO) } & Minimum & 1.00 & 1.00 & 1.00 & 1.00 & 1.00 & 1.00 & 1.00 & 1.00 \\
\hline & Mean & 1.93 & 2.45 & 1.92 & 2.48 & 2.45 & 2.07 & 2.54 & 2.27 \\
\hline & Median & 2.00 & 2.43 & 2.00 & 2.57 & 2.43 & 2.00 & 2.71 & 2.29 \\
\hline & Maximum & 3.57 & 4.29 & 4.14 & 4.29 & 4.29 & 4.14 & 4.29 & 4.29 \\
\hline
\end{tabular}



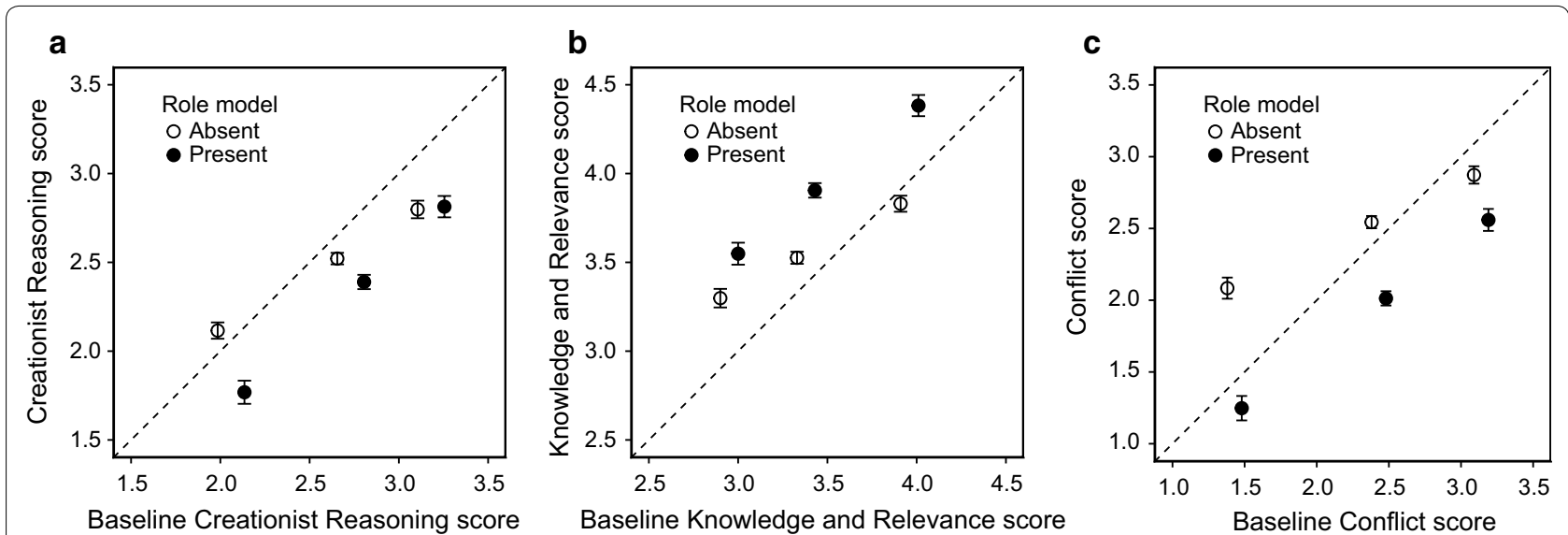

Fig. 1 The effect of presence or absence of a role model instructor on creationist reasoning (a), knowledge and relevance (b), and conflict (c) scores. Model-based estimates (least squares mean \pm one standard error) are computed at three different baseline scores (the 10th, 50th, and 90th percentiles) to illustrate how the role model effect varies with baseline score. Symbols are shifted horizontally to avoid overlap. The dashed line represents equivalence of baseline and end-of-semester scores. Means below the line depict decreased scores over the semester; means above the line depict increased scores

reasoning (CR) scores decreased over the semester (Fig. 1a). The magnitude of the decrease in CR scores depended upon presence or absence of a role model instructor and baseline CR scores. On average, CR scores were lower for students in sections with a rolemodel instructor (role model main effect: $F_{1,789}=15.47$, $\mathrm{p}<0.001)$. This role model effect was more pronounced for students with lower baseline CR scores (role model $\mathrm{x}$ baseline interaction: $F_{1,789}=12.37, p<0.001$ ) and was not evident at high baseline CR scores. Means and standard errors for role model presence and absence, respectively, were $1.77(0.065)$ and $2.12(0.046)\left(\mathrm{t}_{789}=4.64, \mathrm{p}<0.001\right)$ at the 10th percentile; $2.39(0.040)$ and $2.52(0.032)$ $\left(\mathrm{t}_{789}=3.55, \mathrm{p}<0.001\right)$ at the 50th percentile; and 2.81 $(0.060)$ and $2.80(0.050)\left(\mathrm{t}_{789}=-0.30, \mathrm{p}=0.768\right)$ at the 90th percentile. There was no evidence that type of evolution instruction, inclusion of NOS, or major/nonmajor class affected creationist reasoning scores. Neither GPA or baseline religiosity scores were shown to be associated with CR scores or to modify the effects of class section factors.

Knowledge and perceived relevance of evolution (KR) scores generally increased over the semester (Fig. 1b). The magnitude of the increase in $K R$ scores depended upon presence or absence of a role model instructor and baseline KR scores. On average, KR scores were higher for students in sections with a role-model instructor (role model main effect: $\mathrm{F}_{1,789}=108.40, \mathrm{p}<0.001$ ). This role model effect was more pronounced for students with higher baseline KR scores (role model $\times$ baseline interaction: $\left.\mathrm{F}_{1,789}=10.22, \mathrm{p}=0.001\right)$. At all three percentiles of baseline $K R$, the $K R$ score mean for role model presence was higher than the mean for role model absence. Means and standard errors for role model presence and absence, respectively, were $3.55(0.062)$ and 3.30 (0.052) $\left(\mathrm{t}_{789}=-5.43, \mathrm{p}<0.001\right)$ at the 10th percentile; $3.91(0.041)$ and $3.53(0.034)\left(t_{789}=-10.41, p<0.001\right)$ at the 50th percentile; and $4.38(0.060)$ and $3.83(0.045)$ $\left(\mathrm{t}_{789}=-7.54, \mathrm{p}<0.001\right)$ at the 90 th percentile. KR scores at the end of the semester were higher for evidence-based instruction $(3.92 \pm 0.056)$ than conceptual $(3.55 \pm 0.079)$. We determined that there was no evidence that inclusion of NOS or major/nonmajor class affected KR scores. Neither GPA or baseline religiosity scores were shown to be associated with KR scores or to modify the effects of class section factors.

Perceived conflict between evolution and worldview (CO) scores at the end of the semester were lower for students with a role-model instructor (role model main effect: $F_{1,789}=87.45, p<0.001$ ) (Fig. 1c). The magnitude of this role model effect depended upon baseline $\mathrm{CO}$. The role model effect was more pronounced at lower baseline $\mathrm{CO}$ scores (role model $\times$ baseline interaction: $\left.\mathrm{F}_{1,789}=11.69, \mathrm{p}=0.001\right)$. At all three percentiles of baseline $\mathrm{CO}$, the $\mathrm{CO}$ score mean for role model presence was lower than the mean for role model absence. Means (and standard errors) for role model presence and absence, respectively, were $1.25(0.085)$ and $2.08(0.074)$ $\left(\mathrm{t}_{789}=6.52, \mathrm{p}<0.001\right)$ at the 10th percentile; $2.01(0.050)$ and $2.54(0.043)\left(\mathrm{t}_{789}=9.50, \mathrm{p}<0.001\right)$ at the 50th percentile; and $2.56(0.077)$ and $2.87(0.061)\left(t_{789}=5.40\right.$, $\mathrm{p}<0.001)$ at the 90th percentile. For students with a role model instructor, $\mathrm{CO}$ scores decreased over the semester; the decrease was greater for students with higher baseline 
$\mathrm{CO}$ scores. For students without a role-model instructor, the direction of change in $\mathrm{CO}$ scores depended upon baseline $\mathrm{CO}$ scores; $\mathrm{CO}$ scores increased at low baseline $\mathrm{CO}$, increased slightly at mid-baseline $\mathrm{CO}$, and decreased slightly at high baseline $\mathrm{CO}$. There was no evidence that type of evolution instruction, inclusion of NOS, or major/nonmajor class affected perceived conflict scores. Neither GPA or baseline religiosity scores were shown to be associated with $\mathrm{CO}$ scores or to modify the effects of class section factors.

\section{Relationships among constructs}

Our second research goal was to describe patterns among each of our three constructs; specifically, how students' creationist reasoning and their perceived conflict between evolution and their worldview relate to their knowledge and perceived relevance of evolution. We used pre-survey data only to focus on relationships established prior to biology instruction. The first week of the semester, students in our population on average did not have strong creationist (CR) views (mean $\mathrm{CR}=2.67$ on a 5 -point scale), which was interesting given the high degree of religiosity (mean $\mathrm{RA}=4.27$ on a 5 -point scale). On average students began the semester with moderate knowledge (KR) of evolution (mean $\mathrm{KR}=3.41$ on a 5 -point scale) and relatively low perceived conflict (mean $\mathrm{CO}=2.38$ on a 5 -point scale). Students with lower CR scores before biology instruction tended to have lower $\mathrm{CO}$ scores (Spearman $\mathrm{r}=0.28$ ) and higher KR scores (Spearman $r=-0.52$; Fig. 2). Students with higher KR scores had

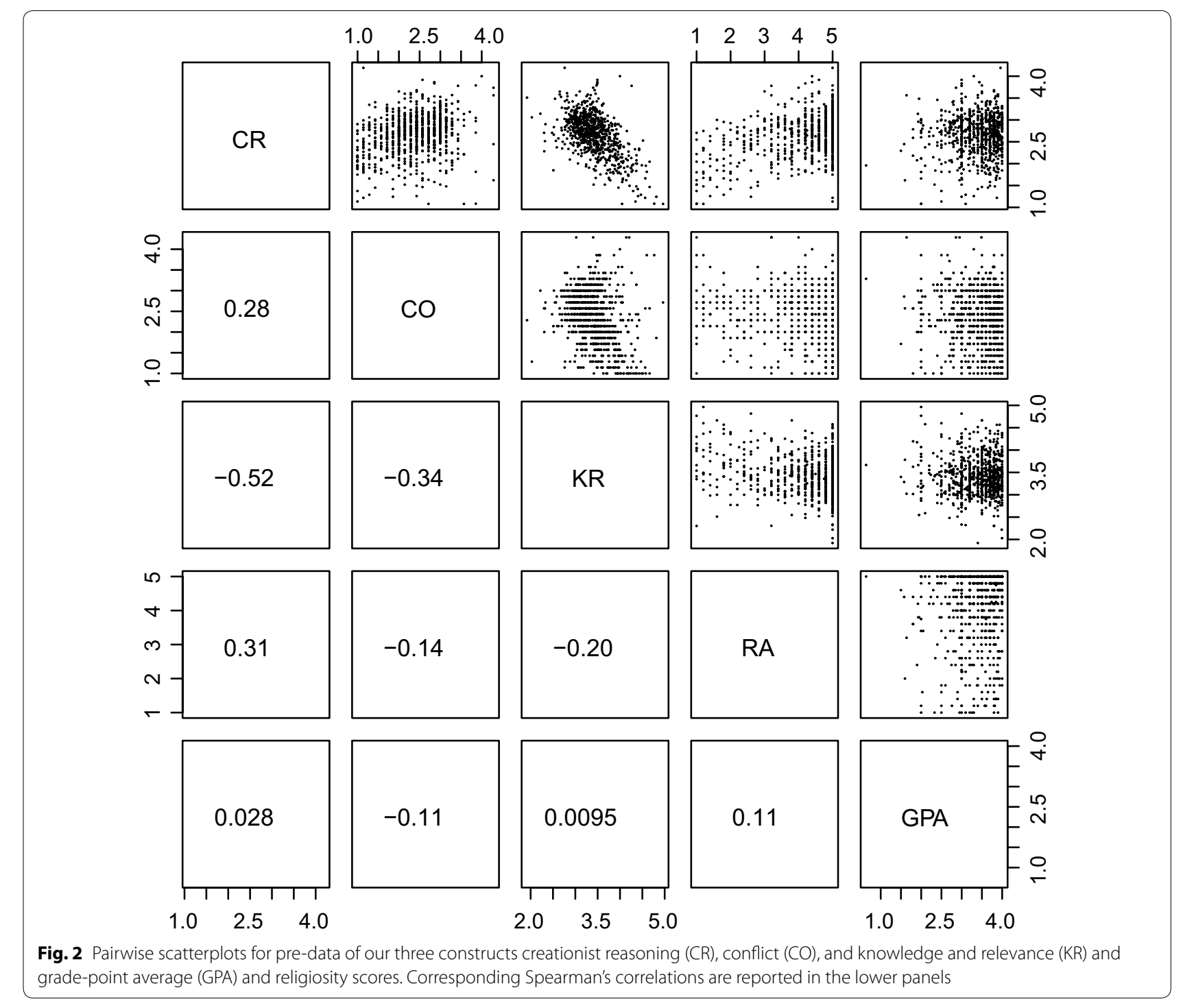


lower perceived CO (Spearman $r=-0.34$; Fig. 2) and reported lower religiosity (Spearman $r=-0.20$ ).

\section{Discussion}

\section{Knowledge is power}

Prior to biology instruction, we found students with lower creationist reasoning and lower perceived conflict between science and their worldview had higher knowledge of evolution. While our study design does not allow us to draw causal inference among variables, these significant relationships highlight two important findings. First, incoming students with deeply held creationist beliefs (i.e., high CR scores) tended to begin the semester with less knowledge of evolution. However, creationist reasoning generally declined following a semester of biology instruction, which may be tied with an increase in evolutionary knowledge.

Second, incoming students who perceive little conflict between evolution and their personal worldview are more knowledgeable about evolutionary science. A semester of evolution instruction, however, did not always reduce perceived conflict in our study. Yet if instruction can successfully lower students' conflict, then they may be more open to learning more evolutionary science. These patterns suggest that evolutionary knowledge does not devalue a student's religious identity but may complement other ways of knowing while minimizing misconceptions. These findings may ease tensions for religious students, who often face external pressure to reject evolution, by affirming that learning about evolution does not degrade the devotion to their faith (Winslow et al. 2011). Yasri and Mancy (2012) identify multiple approaches to low conflict, including compatibility, where science and religion address separate questions; coalescence, where science is God's work (e.g., theistic evolution); or complementarity, where each fills the gaps of the other.

While lacking support in our study, improving understanding of the NOS is elsewhere associated with greater acceptance of evolution (Dunk et al. 2017), which may further remedy high conflict perceived by students. Barnes et al. (2017b) found supplemental NOS discussions supported students' learning of evolution; religious students became aware that compatibility was an option, while nonreligious students recognized that religiosity does not necessarily interfere with one's understanding of evolution.

\section{Role models matter}

In our study, the presence of a role model who both outwardly accepts evolution and is devoted to their faith is the main driver in increasing student knowledge and their understanding of the relevance of evolution, and reducing creationist reasoning and perceived conflict between evolution and a student's personal worldview. While the literature suggests that the type of evolution instruction and student population's major of study influences their acceptance and knowledge of evolution, we did not find the latter factor to be a strong predictor. Yet evidence-based content was associated with greater gains in evolutionary knowledge over instruction using conceptual content only.

Role models (e.g., women in science) have long been recognized to positively impact students' performance and attitudes in science and math (Marx and Roman 2002; Evans and Whigham 1995). Barnes and Brownell (2017) recently identified the presence of a role model as one of six important culturally competent practices in evolution education. Students themselves often credit their lack of conflict to past science or religion instructors (Borgerding et al. 2017). This may be especially true in the case of evolution instruction, where it may be inconceivable to some students that such a combination (i.e., acceptance of evolution and devotion to one's faith) actually exists (Winslow et al. 2011). Our study population, comprising $84 \%$ self-identified Mormons, may benefit even more than a more heterogeneous student population, since Mormonism places a high value on authority and role models. Manwaring et al. (2015) demonstrated that after a discussion among the instructor and students about reconciling evolution with religion, students recognized that LDS doctrine is neutral towards evolution, which empowered the students to form positive viewpoints on evolution.

The presence of a role model positively influenced many aspects of our students' learning about evolution, including increasing accurate knowledge (KR), reducing unsupported ideas (CR), and reducing conflict (CO) over a semester. Previous literature suggests that the role model benefit can be described by identification theories (i.e., where students are motivated to foster perceived similarity with a role model) and social learning theories (i.e., where students learn skills or content from a role model; Akbulut 2016). From the multifaceted benefit demonstrated in our findings, biology students in a highly religious institution may benefit from the heuristic and self-definitional aspects of a role model.

Although the presence of a faculty role model was resoundingly the main driver in changing students' understanding and acceptance of evolution, the baseline value of each construct mediated the size of the role model effect. The presence of a role model improved construct outcomes in general, but was particularly effective for students who did not begin the semester 
with strong creationist beliefs, who were already knowledgeable, and who were not conflicted. Rissler et al. (2014) found a similar trend where the magnitude of change in acceptance decreased with increasing student religiosity, as measured by attendance at religious services. Manwaring et al. (2015) describe that religiosity determined their starting acceptance level, but that religiosity was not associated with how much their acceptance changed over a semester. While the instructors of this latter study (at Brigham Young University, an institution owned by the LDS Church) were likely "religious scientist role models" as well, the student body in our population was more heterogeneous in their levels of religiosity that likely allowed us to detect these differences.

For other students, the effect of a role model was still generally positive but had less impact. Notably students with low conflict in the absence of a role model exhibited increased conflict at the end of the semester. Prior to instruction, these students may have perceived compatibility of evolutionary ideas and their personal worldview; yet, in the absence of a role model, the strict focus on science perhaps left their personal beliefs feeling unsupported. A key recommendation by Schilders et al. (2009) is to dedicate time towards exploring differing worldviews and the potential tension between evolution and some worldviews. This final finding represents the single damaging effect of not having a religious-scientist role model, while the other effects we report represent increasing the size of the benefit otherwise seen simply following biology instruction.

\section{Recommendations for instructors}

Given our findings, the presence of a faculty role model may be a successful way to improve student understanding and perceptions of evolution in populations similar to the one studied here. Yet how does a nonreligious faculty member reach their religious students? In our role model absent treatment, the faculty member discussed accepting views of respected religious authority figures; however, simply telling students that such people or ideas exist is clearly insufficient. Barnes et al. (2017b) demonstrated reduced perceived conflict through a class visit by a religious biologist who discussed his acceptance in conjunction with his faith.

We are unclear if it was the physical presence of a role model (i.e., in contrast to images and quotes of role models) or the personal connection of the role model being their instructor that mattered. In other contexts, Marx and Roman (2002) suggest that the physical presence of a role model alone was inadequate. Further, Winslow et al. (2011) report that a role model in name (i.e., simply stating that someone accepts both evolution and has religious faith) is not sufficient, but that a successful role model must demonstrate their desirable attributes (e.g., lack of conflict between science and their worldview) through action.

Two previous studies (Barnes et al. 2017b; Evans and Whigham 1995) successfully used 1-3 day guest speakers to serve as role models. Both of these studies, however, focused on shifts in attitudes or acceptance of evolution and not on understanding of the science itself. It is unclear if short, informal exposure to a religious scientist could encourage enough change in mindset to induce learning gains and reductions in misconceptions. Undoubtedly, this question needs to be addressed by future research.

\section{Abbreviations}

NOS: nature of science; LDS: Latter-Day-Saints; CR: creationist reasoning; KR: knowledge and perceived relevance of evolution; $\mathrm{CO}$ : conflict between evolution and their worldview.

\section{Authors' contributions}

$\mathrm{EAH}$ and $\mathrm{THO}$ contributed to the experimental design and survey administration. SLD contributed to analysis of our data. All authors drafted the manuscript. All authors read and approved the final manuscript.

\section{Author details \\ ${ }^{1}$ School for Biological Sciences, University of Northern Colorado, Greeley, USA. ${ }^{2}$ Biology Department, Utah Valley University, Orem, USA. ${ }^{3}$ Ecology Center, Utah State University, Logan, USA.}

\section{Acknowledgements}

The authors thank Pat Hawley for her consultation on use of portions of her instrument (EALS). We also recognize Josh Vance and Tanner Mortimer for early contributions on this project. We also acknowledge Sarah Bray for her collaborations, which led to this project.

Competing interests

The authors declare that they have no competing interests.

Availability of data

The authors will share relevant data upon request, in summarized form.

\section{Consent for publication}

Not applicable.

\section{Ethics approval and consent to participate}

The Institutional Review Board of Utah Valley University approved the procedures for this study (IRB \#00943). Written informed consent was obtained by all participating students at the beginning of the study.

\section{Funding}

Not applicable.

\section{Appendix}

See Table 3. 
Table 3 Likert-scale items used in our survey to measure student understanding and acceptance of evolution, derived from Hawley et al. (2011) and Short and Hawley (2012) (EALS) and Bailey et al. (2011) (indicated with *)

\begin{tabular}{|c|c|c|c|c|c|}
\hline Scale $^{a}$ & Original question & Accept $^{\mathbf{b}}$ & Understand ${ }^{\mathbf{c}}$ & Micro-accept ${ }^{d}$ & Conflict $^{\mathrm{e}}$ \\
\hline $\mathrm{R}$ & Are you religious? & N/A & $\mathrm{N} / \mathrm{A}$ & & \\
\hline $\mathrm{R}$ & Does religion impact your daily life-decisions? & N/A & N/A & & \\
\hline $\mathrm{R}$ & Do you participate in religious activities? & N/A & N/A & & \\
\hline $\mathrm{R}$ & I believe in God & N/A & N/A & & \\
\hline $\mathrm{R}$ & $\begin{array}{l}\text { Religion is important to me because it answers many of my questions about the mean- } \\
\text { ing of life }\end{array}$ & N/A & $\mathrm{N} / \mathrm{A}$ & & \\
\hline $\mathrm{R}$ & Are you conservative? & N/A & N/A & & \\
\hline $\mathrm{R}$ & In general, how do you self-identify politically? & N/A & N/A & & \\
\hline $\mathrm{R}$ & $\begin{array}{l}\text { In general, how liberal/conservative are you on social issues (abortion, same-sex mar- } \\
\text { riage, flag burning, etc.)? }\end{array}$ & N/A & N/A & & \\
\hline $\mathrm{R}$ & $\begin{array}{l}\text { In general, how liberal/conservative are you on economic issues (welfare, taxation, free } \\
\text { market policies)? }\end{array}$ & N/A & N/A & & \\
\hline$C R$ & $\begin{array}{l}\text { The present day genetic diversity in the human species can be accounted for by an } \\
\text { original pair of human beings }\end{array}$ & & $x$ & $x$ & \\
\hline$C R$ & The earth is old enough for evolution to have taken place & & $x$ & $x$ & \\
\hline$C R$ & There was a time when humans and dinosaurs lived on earth together & & $x$ & $x$ & \\
\hline$C R$ & God created humans all at once in their present form & & $x$ & $x$ & \\
\hline$C R$ & $\begin{array}{l}\text { I believe that current animal diversity is best explained by the Great Flood during Noah's } \\
\text { life }\end{array}$ & & $x$ & $x$ & \\
\hline$C R$ & $\begin{array}{l}\text { I believe that all modern species of land vertebrates are descended from the animal } \\
\text { pairs that were gathered onto Noah's ark }\end{array}$ & & $x$ & $x$ & \\
\hline$C R$ & I read the Bible literally & N/A & N/A & N/A & \\
\hline$C R$ & I believe that the theory of evolution has contributed to racism & N/A & N/A & $\mathrm{N} / \mathrm{A}$ & \\
\hline$C R$ & I believe that the theory of evolution has contributed to sexism & N/A & N/A & N/A & \\
\hline$C R$ & People who accept evolution do not believe in God & $x$ & & $x$ & \\
\hline$C R$ & People who accept evolution as fact are immoral & $x$ & & $x$ & \\
\hline$C R$ & I believe that Darwinism strips meaning from our lives & $x$ & & $x$ & \\
\hline$C R$ & I believe that people can be moral and believe in evolution at the same time & $x$ & & $x$ & \\
\hline$C R$ & If you accept evolution, you really can't believe in God & $x$ & & $x$ & \\
\hline$C R$ & Human beings were specially designed by an intelligent creator for their role in nature & $x$ & & $x$ & \\
\hline$C R$ & $\begin{array}{l}\text { There is scientific evidence that humans were created by a supreme being or intelligent } \\
\text { designer }\end{array}$ & & $x$ & & \\
\hline$C R$ & There is no evidence that humans evolved from other animals & & $x$ & & \\
\hline$C R$ & $\begin{array}{l}\text { Evolution violates the 2nd law of thermodynamics (that systems move toward disorder, } \\
\text { not order) }\end{array}$ & & $x$ & & \\
\hline$C R$ & $\begin{array}{l}\text { There are no transitional fossils (i.e., remains of life forms that illustrate an evolutionary } \\
\text { transition) }\end{array}$ & & $x$ & & \\
\hline$C R$ & It is statistically impossible that life arose by chance & & $x$ & & \\
\hline$C R$ & $\begin{array}{l}\text { The theory of evolution does not explain similarities or differences between chimps and } \\
\text { humans }\end{array}$ & & $x$ & & \\
\hline$C R$ & I believe that evolution is a theory in crisis & $x$ & $x$ & $x$ & \\
\hline$C R$ & The theory of evolution is a matter of faith and belief, just like religion & $x$ & $x$ & $x$ & \\
\hline$C R$ & Contemporary methods of determining the age of fossils and rocks are untrustworthy & & $x$ & & \\
\hline$C R$ & The data used to support evolution is untrustworthy & & $x$ & & \\
\hline$C R$ & If something is natural then it is good or right & N/A & $\mathrm{N} / \mathrm{A}$ & N/A & \\
\hline KR & Evolutionary theory is highly relevant for biology & & $x$ & $x$ & \\
\hline KR & $\begin{array}{l}\text { Evolutionary theory is relevant to our everyday lives, such as in modern medicine and } \\
\text { modern food production }\end{array}$ & & $x$ & $x$ & \\
\hline $\mathrm{KR}$ & For scientific evidence to be deemed adequate, it must be reproducible by others & & X & & \\
\hline KR & Good theories give rise to testable predictions & & x & & \\
\hline $\mathrm{KR}$ & Good theories can be proven by a single experiment & & $x$ & & \\
\hline
\end{tabular}


Table 3 (continued)

\begin{tabular}{|c|c|c|c|c|c|}
\hline Scale $^{a}$ & Original question & Accept $^{b}$ & Understand $^{c}$ & Micro-accept $^{d}$ & Conflict $^{\mathrm{e}}$ \\
\hline KR & Scientific ideas can be tested and supported by feelings and beliefs & & X & & \\
\hline KR & Scientific explanations can include supernatural evidence & & X & & \\
\hline KR & $\begin{array}{l}\text { Theories requiring more untested assumptions are generally better than theories with } \\
\text { fewer assumptions }\end{array}$ & & $x$ & & \\
\hline $\mathrm{KR}$ & Humans share $99 \%$ of their genes with chimpanzees & & $x$ & $x$ & \\
\hline $\mathrm{KR}$ & Humans share more than half of their genes with mice & & $x$ & & \\
\hline $\mathrm{KR}$ & You can see traces of our evolutionary past in human embryos & & $x$ & & \\
\hline KR & Humans developed from earlier life forms & & $x$ & & \\
\hline KR & Mutations, random changes in the genetic code, are never beneficial & & $x$ & $x$ & \\
\hline KR & In most animal and plant populations, more offspring are born than can survive & & $x$ & $x$ & \\
\hline $\mathrm{KR}$ & Individual organisms don't evolve, species evolve over time & & X & & \\
\hline $\mathrm{KR}$ & Mutations, changes to the genetic code, can be passed down to the next generation & & X & $x$ & \\
\hline KR & Increased genetic variability makes a population more resistant to extinction & & $x$ & $x$ & \\
\hline KR & The more recently species share a common ancestor, the more closely related they are & & $x$ & & \\
\hline KR & Mutations (changes in the genetic code) occur all the time & & X & X & \\
\hline KR & Natural selection is the only cause of evolution & & $x$ & $x$ & \\
\hline $\mathrm{CO}$ & $\begin{array}{l}\text { I am afraid to study science or become a scientist because I fear that science is opposed } \\
\text { to my religious faith* }\end{array}$ & & & & $x$ \\
\hline $\mathrm{CO}$ & $\begin{array}{l}\text { I believe that science and religion are fundamentally opposed to each other and a } \\
\text { person cannot believe in or be committed to both* }\end{array}$ & & & & $x$ \\
\hline $\mathrm{CO}$ & $\begin{array}{l}\text { I believe that science and religion are fully compatible; they address different things and } \\
\text { do not conflict* }\end{array}$ & & & & $x$ \\
\hline $\mathrm{CO}$ & I believe that science and religion complement each other* & & & & $x$ \\
\hline $\mathrm{CO}$ & $\begin{array}{l}\text { A complete view of the world must combine the two ways (science and religion) of } \\
\text { viewing the universe* }\end{array}$ & & & & $x$ \\
\hline $\mathrm{CO}$ & I believe that people can be religious and believe in evolution at the same time* & & & & $x$ \\
\hline $\mathrm{CO}$ & $\begin{array}{l}\text { I believe that science provides the only way to truly understand the world; religion can- } \\
\text { not help us understand the world* }\end{array}$ & & & & $x$ \\
\hline
\end{tabular}

Items which did not directly measure evolution acceptance or understanding are labeled with "N/A"

a Scales: $R$ religiosity, $C R$ creationist reasoning, $K R$ knowledge and relevance of evolution, $C O$ perceived conflict between evolution and personal worldview

b Accept = Students use their level of acceptance of both the mechanisms and result of evolution (i.e., microevolution, macroevolution, and human evolution) to respond to statement

c Understand = Students use their knowledge to respond to statement, regardless of their acceptance level

d Micro-accept =Students use their level of acceptance of microevolution (not human and/or macroevolution) to respond to statement. This designation is always matched with either accept or understand

e Conflict $=$ Students perceive that their personal worldview and ideas of evolution are not compatible

\section{Publisher's Note}

Springer Nature remains neutral with regard to jurisdictional claims in published maps and institutional affiliations.

Received: 16 January 2018 Accepted: 6 August 2018

Published online: 24 August 2018

\section{References}

Abraham JK, Perez KE, Downey N, Herron JC, Meir E. Short lesson plan associated with increased acceptance of evolutionary theory and potential change in three alternate conceptions of macroevolution in undergraduate students. CBE Life Sci Educ. 2012;11:152-64.

Akbulut AY. Major in information systems: an examination of role model influence. J Educ Comput. 2016;54(5):660-79.

Allmon WD. Why don't people think evolution is true? Implications for teaching, in and out of the classroom. Evol Educ Outreach. 2011;4:648-65.
Bailey G, Han J, Wright D, Graves J. Religiously expressed fatalism and the perceived need for science and scientific process to empower agency. Int Sci Soc. 2011;2(3):55-88

Barnes ME, Brownell SE. Practices and perspectives of college instructors on addressing religious beliefs when teaching evolution. CBE Life Sci Educ. 2016;15(2):ar18

Barnes ME, Brownell SE. A call to use cultural competence when teaching evolution to religious college students: introducing Religious Cultural Competence in Evolution Education (ReCCEE). CBE Life Sci Educ. 2017:16(4):1-10.

Barnes ME, Evans EM, Hazel A, Brownell SE, Nesse RM. Teleological reasoning, not acceptance of evolution, impacts students' ability to learn natural selection. Evol Educ Outreach. 2017a;10(1):7.

Barnes ME, Elser J, Brownell SE. Impact of a short evolution module on students' perceived conflict between religion and evolution. Am Biol Teach. 2017b;79(2):104-11.

Barnes ME, Truong JM, Brownell SE. Experiences of Judeo-Christian students in undergraduate biology. CBE Life Sci Educ. 2017c;16(1):ar15. 
Bettinger EP, Long BT. Do faculty serve as role models? The impact of instructor gender on female students. Am Econ Rev. 2005;95(2):152-7.

Bishop BA, Anderson CW. Student conceptions of natural selection and its role in evolution. J Res Sci Teach. 1990;27(5):415-27.

Borgerding LA, Deniz H, Anderson ES. Evolution acceptance and epistemological beliefs of college biology students. J Res Sci Teach. 2017:54(4):493-519.

Bowman KL. The evolution battles in high-school science classes: who is teaching what? Front Ecol Environ. 2008;6(2):69-74

Carter BE, Infanti LM, Wiles JR. Boosting students' attitudes and knowledge about evolution sets them up for college success. Am Biol Teach. 2015;77(2):113-6.

Cavallo AML, McCall D. Seeing may not mean believing: examining students' understandings and beliefs in evolution. Am Biol Teach. 2008;70(9):530-52.

Crapo R. Grass-roots deviance from official doctrine: a study of Latter-Day Saint (Mormon) folk-beliefs. J Sci Study Relig. 1987;26(4):465-85.

Dobzhansky T. Nothing in biology makes sense except in the light of evolution. The American Biology Teacher. 1973;35:125-9.

Dunk RDP, Petto AJ, Wiles JR, Campbell BC. A multifactorial analysis of acceptance of evolution. Evol Educ Outreach. 2017;10(1):4.

Evans MA, Whigham M. The effect of a role model project upon the attitudes of ninth-grade science students. J Res Sci Teach. 1995;32(2):195-204.

Fail J. A no-holds-barred evolution curriculum for elementary and junior high school students. Evol Educ Outreach. 2008;1 (1):56-64.

Gallup Poll. Majority of republicans doubt theory of evolution. http://news. gallup.com/poll/27847/majority-republicans-doubt-theory-evolution. aspx. 2007. Accessed 12 July 2017

Gallup Poll. In US, belief in creationist view of humans at new low. http://news. gallup.com/poll/210956/belief-creationist-view-humans-new-low.aspx. 2017. Accessed 12 July 2017

Gibson DE. Role models in career development: new directions for theory and research. J Vocat Behav. 2004;65:134-56.

Glaze AL, Goldston MJ, Dantzler J. Evolution in the southeastern USA: factors influencing acceptance and rejection in pre-service science teachers. Int J Sci Math Educ. 2015;13:1189-209.

Gould SJ. The structure of evolutionary theory. Cambridge: Harvard University Press; 2002

Hawley PH, Short SD, McCune LA, Osman MR, Little TD. What's the matter with Kansas? The development and confirmation of the Evolutionary Attitudes and Literacy Survey (EALS). Evol Educ Outreach. 2011;4:117-32.

Heddy BC, Nadelson LS. The variables related to public acceptance of evolution in the United States. Evol Educ Outreach. 2013;6:1-6.

Heddy BC, Sinatra GM. Transforming misconceptions: using transformative experience to promote positive affect and conceptual change in students learning about biological evolution. Sci Educ. 2013:97:723-44.

Hermann RS. Elementary education majors'views on evolution: a comparison of undergraduate majors understanding of natural selection and acceptance of evolution. Electron J Sci Educ. 2016;20(6):21-44.

Hokayem H, BouJaoude S. College students' perceptions of the theory of evolution. J Res Sci Teach. 2008:45(4):395-419.

Hurlbert SH. Pseudoreplication and the design of ecological field experiments. Ecol Monogr. 1984:54(2):187-211.

Ingram EL, Nelson CE. Relationship between achievement and students' acceptance of evolution or creation in an upper-level evolution course. J Res Sci Teach. 2006;43(1):7-24.

Kahan DM. A risky science communication environment for vaccines. Science. 2013;342:53-4

Krause NM. Social involvement in religious institutions and God-mediated control beliefs: a longitudinal investigation. J Sci Study Relig. 2007:46(4):519-37.

Lawson AE, Worsnop WA. Learning about evolution and rejecting belief in special creation: effects of reflective reasoning skill, prior knowledge, prior belief and religious commitment. J Res Sci Teach. 1992:29(2):143-66.

Lent RW, Brown SD, Hackett G. Social cognitive career theory. In: Brown D, et al., editors. Career choice and development. 4th ed. NY: Jossey-Bass Company; 2002. p. 255-311.

Lloyd-Strovas JD, Bernal XE. A review of undergraduate evolution education in US universities: Building a unifying framework. Evol Educ Outreach. 2012;5:453-65.
Lombrozo T, Thanukos A, Weisberg M. The importance of understanding the nature of science for accepting evolution. Evol Educ Outreach. 2008:1:290-8.

Manwaring KF, Jensen JL, Gill RA, Bybee SM. Influencing highly religious undergraduate perceptions of evolution: Mormons as a case study. Evol Educ Outreach. 2015;8:1-12.

Marx DM, Roman JS. Female role models: protecting women's math test performance. Pers Soc Psychol Bull. 2002;28:1183-93.

Matthews D. Effect of a curriculum containing creation stories on attitudes about evolution. Am Biol Teach. 2001;63(6):404-9.

Mayr E. The growth of biological thought: diversity, evolution and inheritance. Cambridge: Harvard University Press; 1982.

Mazur A. Believers and disbelievers in evolution. Polit Life Sci. 2005;23(2):55-61.

McCright AM, Dentzman K, Charters M, Dietz T. The influence of political ideology on trust in science. Environ Res Lett. 2013;8:1-9.

Miller JD, Scott EC, Okamoto S. Public acceptance of evolution. Science. 2006;313:765-6.

Moore R, Cotner $\mathrm{S}$. The creationist down the hall: does it matter when teachers teach creationism? Bioscience. 2009;59(5):429-35.

Moore R, Cotner S, Bates A. The influence of religion and high school biology courses on students' knowledge of evolution when they enter college. J Effect Teach. 2009:9(2):4-12.

Moore RD, Brooks C, Cotner S. The relation of high school biology courses and students' religious beliefs to college students' knowledge of evolution. Am Biol Teach. 2011:73(4):222-6.

Nadelson LS, Hardy KK. Trust in science and scientists and the acceptance of evolution. Evol Educ Outreach. 2015:8:1-9.

Nadelson LS, Sinatra GM. Shifting acceptance of evolution: promising evidence of the influence of the Understanding Evolution website. Res. 2010;23(1):13-29

Nadelson LS, Southerland SA. Examining the interaction of acceptance and understanding: How does the relationship change with a focus on macroevolution? Evol Educ Outreach. 2010;3:82-8.

Nehm RH, Schonfeld IS. Does increasing biology teacher knowledge of evolution and the nature of science lead to greater preference for the teaching of evolution in schools? J Sci Teach Educ. 2007:18:699-723.

Nettle D. Understanding evolution may be improved by thinking about people. Evolutionary Psychology. 2010;8(2):205-28.

Newport F. In US, $46 \%$ hold creationist view of human origins: Gallup politics. http://www.gallup.com/poll/155003/hold-creationist-view-human-orig ns.aspx. 2012; Accessed 21 Dec 2016.

Nunnally JC, Bernstein IH. Psychometric theory. 3rd ed. McGraw-Hill: New York; 1994

O'Brien DT, Wilson DS, Hawley PH. "Evolution for Everyone": a course that expands evolutionary theory beyond the biological sciences. Evol Educ Outreach. 2009;2:445-57.

Partin ML, Underwood EM, Worch EA. Factors related to college students' understanding of the nature of science: comparison of science majors and nonscience majors. J Coll Sci Teach. 2013:42(6):89-99.

Paz-y-Miño G, Espinosa A. Assessment of biology majors' versus nonmajors' views on evolution, creationism, and intelligent design. Evol Educ Outreach. 2009;2:75-83.

Pew Research Center. Religious differences on the question of evolution. 2009. http://www.pewforum.org/2009/02/04/religious-differences-on-thequestion-of-evolution/. Accessed 7 Nov 17.

Pew Research Center. Public's views on human evolution. 2013. http:// www.pewforum.org/2013/12/30/publics-views-on-human-evolution/. Accessed 7 Nov 17

Pew Research Center. Religion in Latin America: widespread change in a historically catholic region. 2014. http://www.pewforum.org/2014/11/13/ religion-in-latin-america/. Accessed 7 Nov 17.

Pew Research Center. Views about human evolution among Mormons by religious denomination. 2014. http://www.pewforum.org/religious-lands cape-study/compare/views-about-human-evolution/by/religiousdenomination/among/religious-tradition/mormon/. Accessed 7 Nov 17.

Pew Research Center. US public becoming less religious. http://www.pewfo rum.org/2015/11/03/u-s-public-becoming-less-religious/. 2015. Accessed 7 Nov 17

Pobiner BL. Use human examples to teach evolution. The American Biology Teacher. 2012;74(2):71-2. 
Pobiner BL. Accepting, understanding, teaching, and learning (human) evolution: obstacles and opportunities. Yearb Phys Anthropol. 2016:159:S232-74.

Rissler LJ, Duncan SI, Caruso NM. The relative importance of religion and education on university students' views of evolution in the Deep South and state science standards across the United States. Evol Educ Outreach. 2014;7(1):24.

Romine WL, Todd AN. Valuing evidence over authority: the impact of a short course for middle-level students exploring the evidence for evolution. Am Biol Teach. 2017;79(2):112-9.

Rutledge ML, Mitchell MA. High school biology teachers' knowledge structure, acceptance and teaching of evolution. Am Biol Teach. 2002;64(1):21-8.

Rutledge ML, Warden MA. Evolutionary theory, the Nature of Science and high school biology teachers: critical relationships. Am Biol Teach. 2000;62(1):23-31.

Sager C. Voices for evolution. 3rd ed. Berkeley: National Center for Science Education; 2008.

Schieman S, Pudrovska T, Pearlin LI, Ellison CG. The sense of divine control and psychological distress: variations across race and socioeconomic status. J Sci Study Relig. 2006:45(4):529-49.

Schilders M, Sloep P, Peled E, Boersma K. Worldviews and evolution in the biology classroom. J Biol Educ. 2009;43(3):115-20.
Short SD, Hawley PH. Evolutionary Attitudes and Literacy Survey (EALS): development and validation of a short form. Evol Educ Outreach. 2012;5:419-28.

Stout JG, Dasgupta N, Hunsinger M, McManus MA. STEMing the tide: using ingroup experts to inoculate women's self-concept in science, technology, engineering, and mathematics (STEM). J Pers Soc Psychol. 2011;100(2):255-71.

Wade J. An examination of locus of control/fatalism for blacks, whites, boys, and girls over a two year period of adolescence. Soc Behav Pers Int J. 1996;24:239-48.

Wiles JR. Overwhelming scientific confidence in evolution and its centrality in science education - and the public disconnect. Sci Educ Rev. 2010;9(1):18-27.

Wiles JR, Alters B. Effects of an educational experience incorporating an inventory of factors potentially influencing student acceptance of biological evolution. Int J Sci Educ. 2011:33(18):2559-85.

Winslow MW, Staver JR, Scharmann LC. Evolution and personal religious belief: Christian University biology-related majors'search for reconciliation. J Res Sci Teach. 2011;48(9):1026-49.

Yasri P. Mancy R. Understanding student approaches to learning evolution in the context of their perceptions of the relationship between science and religion. Int J Sci Educ. 2012;36(1):24-45.
Ready to submit your research? Choose BMC and benefit from:

- fast, convenient online submission

- thorough peer review by experienced researchers in your field

- rapid publication on acceptance

- support for research data, including large and complex data types

- gold Open Access which fosters wider collaboration and increased citations

- maximum visibility for your research: over 100M website views per year

At BMC, research is always in progress.

Learn more biomedcentral.com/submissions 